\title{
СОЦІАЛЬНО-ПСИХОЛОГІЧНІ ОСОБЛИВОСТІ ПРОСОЦІАЛЬНОЇ ПОВЕДІНКИ У ПІДЛІТКОВОМУ ВІЦІ
}

У статті здійснено аналіз соџіальних та психологічних особливостей просоџіальної поведінки у підлітковому віці. Розкрито тлумачення просоиіальної поведінки у працях вітчизняних та зарубіжних дослідників. Визначено відмінності просоиіальної та альтруїстичної поведінки. Здійснено огляд теорій альтруїстичної поведінки. Охарактеризовано особливості особистості підліткового періоду життя,висвітлено сочіальні й психологічні особливості підлітка в складних умовах сучасного соціуму. Визначено, щуо просоиіальна спрямованість поведінки підлітків має неоднозначний та дискусійний характер, оскільки перебуває у стадії формування, а досліджуваний вік є сентизивним для розвитку просочіальності.

Ключові слова: альтруїзм, просочіальність, просоціальна поведінка, підліток, підлітковий вік, соціальні особливості, психологічні особливості, соціум.

В статье осуществлен анализ социальных и психологических особенностей просоциального поведения в подростковом возрасте. Раскрыто толкование просоииального поведения в трудах отечественных $и$ зарубежных исследователей. Определены различия просоииального $u$ альтруистического поведения. Осуществлен обзор теорий альтруистического поведения. Охарактеризованы особенности личности подросткового периода жизни, раскриты соииальные и психологические особенности подростка в сложных условиях современного сочиума. Определено, что просоииальная направленность поведения подростков имеет неоднозначный и дискуссионный характер, поскольку находится в стадии формирования, а исследуемый возрасной период является сензитивным для развития просоциальности.

Ключевые слова: альтруизм, просочиальнисть, просочиальное поведение, подросток, подростковый возраст, сочиальные особенности, психологические особенности, сочичм.

Постановка проблеми. Питання морально-етичної поведінки, позитивної міжособистісної взаємодії є одним з актуальних тем сучасних досліджень у галузі психології, педагогіки та соціології. Дії людини на благо інших трактуються як феномен просоціальної поведінки. Нині проблема дослідження зазначеного феномену є значущою у зв'язку із соціально-економічними перетвореннями суспільства, науково-технічним прогресом, зміною морально-етичних цінностей та норм поведінки. Зазначені перетворення трансформують не лише саме поняття просоціальної поведінки, але й психологічний портрет особистості сучасної дитини-підлітка. Сучасна особистість підліткового віку значно відрізняється від своїх однолітків минулих поколінь. Тому визначення особливостей просоціальної поведінки дітей підліткового віку є актуальною проблемою психологічної науки.

Аналіз останніх досліджень і публікацій. Незважаючи на те, що закономірності сутності та природи просоціальності для психологічної науки є відносно новою віхою наукового аналізу, цій проблемі присвячено багато наукових досліджень. Перші спроби дослідження проблеми просоціальної поведінки розглядалися в рамках вивчення альтруїзму, емпатії, моральності, кооперативної поведінки. Сам термін «просоціальна поведінка» 3'явився з середини XX століття. У загальному, в психологічному дискурсі виділяють два основних підходи до визначення поняття «просоціальної поведінки». Перший ототожнює соціальну поведінку і альтруїзм 3 діями, які вчиняються виключно на благо іншої людини (С. П. Ільїн, В.Г. Крисько, Х. Хекхаузен). Другий підхід тлумачить цей тип поведінки як будь-які дії, що здійснюються не тільки на благо іншої 
людини, але і заради власної вигоди (Е. Аронсон, Т. Вілсон і Р. Ейкерт, Д. Бетсон, Г. Карло і Б.А. Рендалл, Н.В. Корчакова, Д. Кенрика і С. Нейберг, І.М. Кондаков, Я. Рейковский, Ш. Тейлор, Р. Чалдіні).

Проблему просоціальної поведінки розглядали вітчизняні та зарубіжні дослідники, такі як К. Абульханова-Славська, В. Абраменкова, С. Адлер, Дж. Бендор, Б. Братусь, Ф. Василюк, Дж. Вотсон, П. Кропоткін, Н.В. Корчакова, В. Куницина, О. Леонтьєв, А. Маслоу, Р. В. Павелків, С. Рубінштейн, В. Русалов, В. Ядов, І. Ялом та інші.

Формулювання цілей статті. Здійснити теоретичний аналіз психологічних та соціальних особливостей просоціальності в період підліткового віку. Відповідно до поставленої мети, варто вирішити наступні завдання: розкрити сутність поняття «просоціальна поведінка»; охарактеризувати особливості підліткового віку; висвітлити соціальні й психологічні особливості просоціальної поведінки сучасного підлітка.

Виклад основного матеріалу дослідження. Нині у науці немає єдиного визначення терміна просоціальної поведінки і теорій, які його пояснюють. Для дослідження соціально-психологічних особливостей просоціальної поведінки підлітків, вважаємо за доцільне здійснити аналіз змісту поняття просоціальної поведінки.

Так, у психологічному словнику за редакцією В. І. Войтка подано таке визначення просоціальної поведінки: «це поведінка індивіда, що орієнтується на благо соціальних груп, надання допомоги. Вона зумовлюється переважно намірами бути корисним іншим і найчастіше проявляється у допомозі, участі чи співпраці, взаємодії, суспільному служінні. Відповідно до цього, можуть бути задіяні такі ресурси допомоги ближньому чи суспільству: увага, час, праця, грошові видатки, відсування на задній план власних бажань і планів, безкорисливе соціальне служіння, самопожертва тощо» [9]. У психологічному словнику I.M. Кондакова зазначено, що просоціальна поведінка спрямована, перш за все, на збереження, захист, полегшення функціонування розвитку соціальних спільнот (іншої людини, колективу, громадської організації, культурної норми тощо [4]. Таким чином, просоціальна поведінка - це тип поведінки особистості, що передбачає будь-який вид допомоги на користь соціальних спільнот.

Просоціальна поведінка, згідно з 3. Лінденбергом, це найбільш загальний термін для видів поведінки, пов'язаних інтенціонально з благополуччям іншого, можливо і з урахуванням власних інтересів, проте така поведінка неодмінно передбачає деякі жертви для суб'єкта просоціальної поведінки. Вчений вирізняє п'ять видів просоціальної поведінки: 1) співпраця, 2) справедливість, 3) альтруїзм, 4) надійність, 5) повага до інтересів інших. Всі ці види приносять благо іншому і сприймаються як поведінка, що вимагає від суб'єкта певної жертовності [12, с. 24]. За визначенням вченого, термін просоціальна поведінка є загальним i передбачає як альтруїстичні наміри, так і особистісну вигоду, однак основним «ядром» цього терміна є здатність особистості до жертовності.

Більшість дослідників у галузі соціальної психології (Д. Майерс, В. Джеймс, Л. Мерфі, В. Стауб, Р. Чалдіні, А. Айзенберг) і педагогіки (І. Бех, Б. Братусь, О. Леонтьєв, С. Рубінштейн, М. Фіцула) характеризують просоціальну поведінку як позитивну, конструктивну, соціально корисну поведінку; пряму протилежність антисоціальній поведінці. Просоціальну поведінку дослідники (Л. Калашникова та інші) розглядають також як систему певних моральних якостей, відносин, які визначаються специфічними почуттями, потребами, мотивами, навичками поведінки; особливу форму внутрішньої самоактивності, що дає людині змогу наслідувати моральні норми.Психолог Є.П. Ільїн ототожнює альтруїстичну та просоціальну поведінку, оскільки під останньою він розуміє поведінку, що спрямована на благо інших і не розрахована на будь-яку зовнішню нагороду. Така поведінка більшою мірою веде до благополуччя іншої людини, ніж самого суб'єкта, і обумовлена не зовнішнім соціальним тиском і не присутністю людини, а наявністю у суб'єкта допомоги ряду душевних якостей (особистісних диспозицій) - співчутливості, дбайливості, почуття обов'язку, відповідальності [3].

В психологічній літературі існують три основні теорії альтруїстичної поведінки: теорія соціального обміну, теорія соціальних норм, теорія еволюційної психології, що визначають основні мовити цього типу поведінки. Теорія соціального обміну пояснює, що альтруїстична поведінка має на меті певні корисні для іншої особи результати і приховані корисні наслідки для діючої особи (визнання, статус, інформація тощо). Ці корисні результати можуть бути як внутрішньою, так і зовнішньою винагородою. Наприклад, дослідники (М. Снайдер, А. Омото, Д. Клері цит. за 7) вказують, що існує ряд причин, які пояснюють, чому люди добровільно надають допомогу тим, хто хворіє на СНІД: прагнення до знань, кар'єристичні мотиви, мотиви соціального пристосування, захист свого Я, ріст самоповаги, вираз цінностей [7]. Таким чином, діючи на благо інших людина має для себе користі наслідки цієї діяльності, у процесі допомоги здійснюється обмін соціальними 
здобутками. Ця теорія зазначає, що будь-які альтруїстичні дії можуть мати прихований (навіть для самої особи) позитивний наслідок, як наприклад, набуття соціального досвіду. Теорія соціальних норм пояснює альтруїстичну поведінку тим, що цей тип поведінки диктується сукупністю впорядкованих норм: люди повинні допомагати один одному; в першу чергу, слід допомагати тому, хто допомагає нам тощо (Алвін Гоулднер, цит. за 7). Існує цілий ряд норм, які визначають міру допомоги іншим людям. Ці норми є своєрідними каузально-атрибутивними схемами, які дають людям орієнтири при виникненні ситуації з необхідністю допомоги іншим людям. Тобто, допомога іншим зумовлена усталеними суспільними цінностями, і людина, будучи суспільною істотою, має цих норм дотримуватись. Еволюиійна теорія альтруїзму (Р. Докінз, Д. Кампбел, Є. Уілсон, цит. за 7). Головна ідея цієї теорії полягає в тому, що для індивіда доцільною є лише та активність, яка забезпечує виживання його роду. Люди, схильні безкорисливо діяти в інтересах інших, не зможуть вижити в ході еволюційних змагань, тому доцільним є тільки добре вивірений альтруїм, що забезпечує захист роду (тих, які генетично схожі з нами) і пошук взаємної вигоди. Однією з таких доцільних форм альтруїзму є батьківська та материнська відданість і любов до своїх дітей [7]. Згідно зазначених теорій, допомога іншим детермінується закладеними генетичними мотивами продовження роду, сформованими соціальними нормами та особистісними (прихованими або ні) мотивами. 3 цього приводу Т. В. Гольцева зазначає, що до теперішнього часу немає чіткого уявлення про співвідношення між альтруїстичною поведінкою і здатністю дотримуватися моральних норм, між дотриманням норм і моральними судженнями, між моральними судженнями і переживаннями [1].

Науковці Р. Чалдини, Д. Кенрик і С. Нейберг теж вважають, що здійснення просоціальної поведінки в різних ситуаціях пояснюється мотиваџією надання допомоги. Відповідно до цього, вчені пропонують виділення трьох видів такої поведінки. На думку авторів, просоціальну поведінку характеризують вчинки, що здійснюються однією людиною для іншого і заради його користі. Це визначення $є$ правильним і в тому випадку, коли допомагаючий теж отримує користь. Усередині цієї категорії існує більш обмежений тип, так званий прояв доброти. У цьому випадку вчинок приносить користь іншому, але не дає зовнішньої винагороди або визнання самому допомагаючому. Ще більш обмежений тип поведінки характеризує поведінку, спрямовану на те, щоб принести користь іншій людині, і такі дії відбуваються виключно заради добробуту іншого - це так званий чистий (або справжній) альтруїзм (Batson \& Shaw, 1991) [10]. Так, Е. Аронсон, Т. Вілсон і Р. Ейкерт також розмежовують просоціальну поведінку та альтруїзм. Вони розуміють соціальну поведінку як будь-які діï, вчинені з метою принести користь іншій істоті. При цьому людина може діяти просоціально заради власної вигоди (сподіватися отримати щось натомість), або іiі дії можуть бути продиктовані виключно бажанням принести користь іншому, без будь-якої користі для самого себе - в даному випадку вже йдеться про альтруїзм [1].

Словник-довідник з соціальної психології під редакцією В. Крисько визначає просоціальну поведінку як «вчинок, який допомагає іншим або спрямований на благо оточуючих, але при цьому таїть в собі певний ризик для самого благодійника» [6, с. 226]. Тоді як альтруїзм визначається як «різновид суспільної поведінки, коли одна людина добровільно допомагає іншій з тими чи іншими витратами для себе» [6, с. 11]. У даному випадку акцент здійснено на те, що, здійснюючи альтруїстичний вчинок допомагаючий несе певні витрати, при здійсненні ж просоціального вчинку може мати місце певна вигода не тільки для одержувача допомоги, а й для допомогаючого. Просоціальну поведінку ми розуміємо у найбільш загальному вигляді, як поведінку, що здійснюються з метою допомоги на користь соціальних спільнот. Ця поведінка також передбачає отримання користі допомагаючим, що відрізняє ії від альтруїстичної поведінки.

Традиційно підлітковий вік відносять до критичних періодів онтогенезу й вважають найважчим у процесі виховання. Просоціальна поведінка формується під впливом внутрішніх детермінант та ускладнюється в процесі онтогенетичного і особистісного становлення індивіда, як складова системи соціальної компетентності. Підлітковий вік розглядається як гостроплинний перехід від дитинства до дорослості, в якому опукло переплітаються суперечливі тенденції. У цей найкоротший період підліток проходить великий шлях у своєму саморозвитку. Важливість вивчення соціально-психологічних особливостей просоціальної поведінки у підлітковому віці, підсилюється тим, що саме у цей період відбувається різносторонній процес становлення і розвитку підлітка у всіх напрямках. Відбувається становлення якісних новоутворень внаслідок перебудови організму паралельно з трансформаційними процесами взаємин з дорослими та однолітками, освоєння нових способів соціальної взаємодії, розширення в уяві підлітка змісту морально-етичних норм, розвитку самосвідомості, інтересів, пізнавальної та навчальної діяльності тощо.

За даними психологічного обстеження підлітків за допомогою методики діагностики міжособистісних стосунків Т.Лірі, науковець Г. В Рудь визначила розподіл підлітків за шкалою 
альтруїзму. Серед них: 31,25\% мають низький рівень, 37,5\% - помірний, 31,25\% - високий рівень. Для третини учнів характерно гіпервідповідальність, принесення в жертву своїх інтересів, прагнення допомогти і співчувати всім. Дві третини учнів відповідальні, делікатні, м'які та добрі, співчутливі, вміють підтримувати і заспокоювати, є безкорисливими. Автор визначила, що для хлопчиків більш характерними є крайні вираженості поведінки - низькі та екстремальні значення. Для дівчаток помірковані відповіді, 3 тенденцією до середнього. Немає вагомої різниці у показниках авторитаризму, підозрілості, поступливості, альтруїзму та залежності. Для хлопців більш характерним $є$ вияви дружелюбності та агресії, для дівчаток - егоїзму емпатії та альтруїзму [10].

Емпіричне дослідження Л. П. Мельник, О. М. Чайковської показало, що у підлітків спостерігаються такі просоціальні тенденції як: поступливість, публічність, емоційність. Також для підлітків характерним при наданні допомоги є оцінка витрат, програшів та винагороди. На індивідуальному рівні у підлітків переважають цінності безпеки, самостійності та доброзичливості. У підлітків переважають егоїстичні мотиви, а серед юнаків більше альтруїстів. Рівень розвитку відчуття емпатії в учнів юнацького віку значно вищий, ніж в учнів підліткового віку. Тому, ми можемо констатувати недостатній розвиток просоціальної поведінки як у підлітковому віці так і в юнацькому, що двояко виражає особливості про соціальної поведінки у даному віці [8, с. 144-145].

Аналізуючи проблему траєкторії вікового розвитку просоціальної поведінки, Н. В. Корчакова, на основі власних досліджень та аналізу робіт зарубіжних учених, теж зауважила на дискусійність висновків щодо просоціальної спрямованості поведінки підлітків. У загальному автор зазначила, що існують підстави стверджувати, що посилення просоціальних тенденцій відбувається під час дорослішання особистоті [4, с. $77-78]$.

Висновки та перспективи досліджень. Аналіз наукових досліджень дозволяє зробити висновки, що неоднозначність трактувань поняття просоціальної поведінки, а також психологічних особливостей просоціальної поведінки у підлітковому віці $є$ актуальною проблемою сьогодення. Просоціальну поведінку ми розуміємо у найбільш загальному вигляді, як поведінку, що здійснюються з метою допомоги на користь соціальних спільнот. Ця поведінка також передбачає отримання користі допомагаючим, що відрізняє іiі від альтруїстичної поведінки. Теоретичне дослідження публікацій з проблеми вивчення соціально-психологічних особливостей просоціальної поведінки у підлітковому віці дозволяє зробити висновки, що це питання є малодослідженим і дискусійним. Підлітковий вік, як кризовий період розвитку особистості, передбачає формування усталених норм поведінки, комплексу моральних цінностей, принципів, усвідомлення власного Я тощо. У зв'язку з цим, існує неоднозначність у ставлення дитини-підлітка до допомоги іншим. Саме у цей період відбувається трансформація моральних пріоритетів, тому він $є$ найбільш сентизивним для розвитку просоціальних мотивів.

Перспективою подальших досліджень у цьому напрямі вважаємо емпіричне дослідження психологічних собливостей просоціальної поведінки дітей підліткового віку, визначення домінантних мотивів просоціальної поведінки підлітків.

\section{Список використаних джерел}

1. Аронсон Э. Социальная психология : психологические законы поведения человека в социуме / Э. Аронсон, Т. Уилсон, Р. Эйкерт. - СПб. : Прайм-Еврознак, 2002. - 556 с.

2. Гольцева Т. В. Особенности альтруистических представлений детей старшего дошкольного и младшего школьного возраста : автореф. дис. ... канд. психол. наук / Т. В. Гольцева. Орел, 2004. - 21 c.

3. Ильин Е. П. Мотивация и мотивы / Е. П. Ильин. - СПб. : Питер, 2002. - 512 с.

4. Кондаков И. М. Психологический словарь / И. М. Кондаков. - М. : «ОЛМА Медиа Групп», «ОЛМА Пресс Образование», 2007. - 512 с.

5. Корчакова Н. В. Траєкторія вікового розвитку просоціальної поведінки / Н. В. Корчакова // Науковий вісник Херсонського державного університету. Серія : Психологічні науки. - 2015. - Вип. 4. - С. 76-80.

6. Крысько В. Г. Словарь-справочник по социальной психологии / В. Г. Крысько. - СПб. : Питер, 2003. -416 с.

7. Майерс Д. Социальная психология /Д. Майерс ; пер. с англ. - СПб. : Питер. 1997. - 688 с.

8. Мельник Л. П. Особливості просоціальної поведінки в підлітковому та юнацькому віці / Л. П. Мельник, О. М. Чайковська // Збірник наукових праць Кам'янець-Подільського національного університету імені Івана Огієнка. Серія : Соціально-педагогічна. - 2016. -Вип. 27. - С. 135-146.

9. Психологічний словник / за ред. В. І. Войтка. - Київ : Вища шк., 1982. - 215 с. 
10. Рудь Г. В.Психологічні особливості просоціальної поведінки підлітків / Г. В. Рудь // Психологія: реальність і перспективи : зб. наук. пр. Рівнен. держ. гуманіт. ун-ту. - 2013. - Вип. 2. - С. $161-166$.

11. Чалдини Р. Социальная психология. Пойми других, чтобы понять себя! / Р. Чалдини, Д. Кенрик, С. Нейберг. - СПб. : Прайм-Ерознак ; Нева ; М. : Олма-пресс, 2002. - 256 с.

12. Lindenberg S. Prosocial Behavior, Solidarity, and Framing Processes / S. Lindenberg // Solidarity and Prosocial Behavior An Integration of Sociological and Psychological Perspectives. Springer Science + Business Media, Inc, 2006. - P. 23-45.

\section{References}

1. Aronson Je. Social'naja psihologija : Psihologicheskie zakony povedenija cheloveka v sociume / Je. Aronson, T. Uilson, R. Jejkert. - SPb. : Prajm-Evroznak, 2002. - 556 s.

2.Gol'ceva T. V. Osobennosti al'truisticheskih predstavlenij detej starshego doshkol'nogo i mladshego shkol'nogo vozrasta : avtoref. dis. ... kand. psiholog. nauk / T. V. Gol'ceva. - Orel, 2004. - 21 s.

3. Il'in E. P. Motivacija i motivy / E. P. Il'in. - SPb. : Piter, 2002. - $512 \mathrm{s.}$

4. Kondakov I. M. Psihologicheskij slovar' / I. M. Kondakov. - M. : «OLMA Media Grupp», «OLMA Press Obrazovanie», 2007. - 512 s.

5. Korchakova N. V. Trayektoriya vikovogo rozvy`tku prosocial’noyi povedinky` / N. V. Korchakova // Naukovy`j visny`k Xersons`kogo derzhavnogo universy`tetu. Seriya : Psy`xologichni nauky`. - 2015. - Vy`p. 4. - S. 76-80.

6. Krys'ko V. G. Slovar'-spravochnik po social'noj psihologii / V. G. Krys'ko. - SPb. : Piter, 2003. $-416 \mathrm{~s}$.

7. Majers D. Social'naja psihologija / D. Majers ; per. s angl. - SPb. : Piter. 1997. - 688 s.

8. Mel`ny`k L. P. Osobly`vosti prosocial`noyi povedinky` v pidlitkovomu ta yunacz`komu vici / L. P. Mel`ny`k, O. M. Chajkovs`ka // Zbirny`k naukovy`x pracz`Kam'yanecz`-Podil`s`kogo nacional'nogo universy`tetu imeni Ivana Ogiyenka. Seriya : Social`no-pedagogichna. - 2016. -Vy`p. 27. - S. 135-146.

9. Psy`xologichny`j slovny`k / za red. V. I. Vojtka. - Kyyiv : Vy`shha shk., 1982. - 215 s.

10. Rud` G. V. Psy`xologichni osobly`vosti prosocial noyi povedinky` pidlitkiv / G. V. Rud // Psy`xologiya: real'nist` i perspekty`vy`. -2013. - Vy`p. 2. - S. 161-166.

11. Chaldini R. Social'naja psihologija. Pojmi drugih, chtoby ponjat' sebja! / R. Chaldini, D. Kenrik, S. Nejberg. - SPb. : Prajm-Eroznak ; Neva ; M. : Olma-press, 2002. - 256 s.

12. Lindenberg S. Prosocial Behavior, Solidarity, and Framing Processes / S. Lindenberg // Solidarity and Prosocial Behavior An Integration of Sociological and Psychological Perspectives. Springer Science + Business Media, Inc, 2006. - P. 23-45.

\section{N. Z. Derevyanko SOCIO-PSYCHOLOGICAL CHARACTERISTICS PROSOCIAL BEHAVIOR IN ADOLESCENCE.}

The analysis of scientific research allows us to conclude that the ambiguity of the interpretation of the concept of prosocial behavior, as well as the psychological characteristics of social-behavioral behavior in adolescence, is an actual problem of the present. The article deals with the interpretation prosocial behavior in the works of national and foreign researchers. The historical aspects of the emergence of the problem of prosociality is determinate. Prosocial behavior is a type of person's behavior that involves any kind of assistance in favor of social communities.

The differences of prosocial and altruistic behavior are determined. Prosocial behavior involves receiving the benefit of helping, distinguishing it from altruistic behavior. An overview of the theories of altruistic behavior is given. They are the theory of social exchange, the theory of social norms, the theory of evolutionary psychology. The peculiarities of the personality of the teenage period of life are characterized, social and psychological peculiarities of the adolescent are described in the difficult conditions of modern society. It is determined that the prosocial orientation of behavior of adolescents is ambiguous and controversial, since it is in the stage of formation. In this regard, there is ambiguity in the attitude of the child-teenager to helping others. It is during this period that the transformation of moral priorities takes place.

The prospect of further research in this area is considered an empirical study of psychological peculiarities of social behavior in adolescent children.

Key words: altruism, prosocial, prosocial behavior, teenager, adolescence, social features, psychological peculiarities, socium. 